\title{
DYSLIPIDEMIA IN THYROID DISORDERS
}

\section{Dr. Daulat Meena ${ }^{1}$, Dr. Ramavatar Bairwa ${ }^{2}$}

${ }^{1}$ Assistant Professor, ${ }^{2}$ Junior Specialist Department of General Medicine, RVRS Medical College, Bhilwara

Article Info: Received 26 November 2019; Accepted 14 December 2019

DOI: https://doi.org/10.32553/ijmbs.v3i12.804

Corresponding author: Dr. Ramavatar Bairwa

Conflict of interest: No conflict of interest.

\section{Abstract}

Background: Thyroid hormones have profound metabolic effects, the most striking action being an increase in energy expenditure. Thyroid hormones play an important role in regulating lipid metabolism; and thyroid dysfunctions can result in lipid abnormalities which increase the risk of endothelial dysfunction, hypertension and cardiovascular disease.

Methods: A cross-sectional study was conducted on 100 patients with suspicion of thyroid disorders were taken as cases. One hundred patients with normal thyroid profile and no history of other chronic diseases were taken as control group.

Results- The serum TC, TG and LDL levels in hypothyroid individuals (both overt and subclinical) were significantly higher than euthyroid subjects but the levels were comparable between hyperthyroid and euthyroid group.

Conclusion: We conclude that, dyslipidemias are associated with thyroid disorders, so biochemical screening for thyroid dysfunction in all dyslipidemic patients. Therefore, patients presenting with dyslipidemia are recommended for investigation to explore thyroid dysfunction.

Keywords: Total cholesterol, Triglycerides and LDL.

\section{Introduction}

Thyroid hormones have profound metabolic effects, the most striking action being an increase in energy expenditure ${ }^{1,2}$. Thyroid hormones play an important role in regulating lipid metabolism; and thyroid dysfunctions can result in lipid abnormalities which increase the risk of endothelial dysfunction, hypertension and cardiovascular disease ${ }^{3}$. It is well known that alterations in thyroid functions result in changes in the composition and transport of lipoproteins ${ }^{4-6}$. In hyperthyroidism, the metabolic effects include the increased utilization and oxidation of all major fuel substrates that is, protein, glucose and lipids. The metabolic effects of hypothyroidism are not well characterized. The condition is characterized by increased fasting plasma cholesterol and triglycerides 7,8 . The effects of hypothyroidism on HDL cholesterol level has been contradictory. HDL cholesterol levels have been reported to be increased ${ }^{8}$ decreased ${ }^{9}$ and normal ${ }^{10}$ in hypothyroidism. It is well-known that hypothyroidism is associated with hypercholesterolemia and increases the risk of atherosclerosis ${ }^{11,12}$
Hyperlipidemia observed in hypothyroidism is a metabolic result currently treatable with thyroid hormone. Before the availability of sensitive thyroid hormone analysis, increased serum or plasma cholesterol level was accepted as important evidence supporting the diagnosis of hypothyroidism ${ }^{13}$ Classical signs and symptoms of clinical hypothyroidism may not be observed when it is mild or moderate. The present study was planned to assess the levels of total cholesterol (TC), LDLcholesterol, VLDL-cholesterol, HDL-cholesterol and triglyceride (TG) in patients with thyroid dysfunction (hypo and hyperthyroidism) and to study the association between thyroid dysfunction and lipid profile.

\section{MATERIALS AND METHODS}

A cross-sectional study was conducted on 100 patients with suspicion of thyroid disorders were taken as cases. One hundred patients with normal thyroid profile and no history of other chronic diseases were taken as control group. Detailed informations of the patients were collected after taking informed consent with the help of pre-test 
proforma that included age, sex and family or personal history of chronic diseases.

After 12 hours overnight fasting, $5 \mathrm{ml}$ blood was collected by standard venipuncture method, and the serum was separated. T3, T4 and TSH were quantitatively estimated by Enzyme linked immunosorbent assay (ELISA) method.

Lipid profile measured following methods

$>$ Serum total cholesterol: was measured by Enzymatic method Normal serum cholesterol: 150$250 \mathrm{mg} / \mathrm{dl}$
$>$ Serum HDL cholesterol: was measured by "Phosphotungstate method. Normal HDL Cholesterol: $30-70 \mathrm{mg} / \mathrm{dl}$.

$>$ Serum LDL cholesterol: If the value of Triglycerides is known, LDL-cholesterol can be calculated based on Friedewald"s equation.

> Serum Triglycerides: was measured by enzymatic colorimetric method Normal Serum Triglycerides: Male: $60-165$ mg/dl Female: $40-140 \mathrm{mg} / \mathrm{dl}$.

\section{RESULTS}

Table 1: Comparison of biochemical parameters in case and controls.

\begin{tabular}{|l|l|l|l|l|l|}
\hline Parameters & $\begin{array}{l}\text { Subclinical } \\
\text { hypothyroidism }\end{array}$ & $\begin{array}{l}\text { Overt } \\
\text { hypothyroidism }\end{array}$ & $\begin{array}{l}\text { Subclinical } \\
\text { hperthyoidism }\end{array}$ & $\begin{array}{l}\text { Overt } \\
\text { hypothyroidism }\end{array}$ & Control \\
\hline TC & $264.12 \pm 71.02$ & $296.4 \pm 75.12$ & $181.2 \pm 60.23$ & $144.45 \pm 11.20$ & $135.1 \pm 12.38$ \\
\hline LDL & $97.86 \pm 16.54$ & $124.1 \pm 36.24$ & $92.2 \pm 22.84$ & $82.4 \pm 7.84$ & $81.2 \pm 11.24$ \\
\hline HDL & $45.20 \pm 13.20$ & $32.51 \pm 7.84$ & $37.48 \pm 6.48$ & $37.11 \pm 6.08$ & $54.23 \pm 13.72$ \\
\hline TG & $206.4 \pm 48.24$ & $235.24 \pm 38.1$ & $116.8 \pm 24.81$ & $60.47 \pm 4.13$ & $80.23 \pm 11.24$ \\
\hline
\end{tabular}

The serum TC, TG and LDL levels in hypothyroid individuals (both overt and subclinical) were significantly higher than euthyroid subjects but the levels were comparable between hyperthyroid and euthyroid group.

\section{DISCUSSION}

Thyroid dysfunction, along with a higher prevalence of goiter, is a major public health problem in India population. In this study, the prevalence of hypothyroidism was higher than hyperthyroidism similar finding observed by findings by Baral et al. ${ }^{14}$ and Holowell et al. ${ }^{15}$

The serum TC and LDL levels in hypothyroid individuals (both overt and subclinical) were significantly higher than euthyroid subjects but the levels were comparable between hyperthyroid and euthyroid group in our study.

Jung ${ }^{16}$ found mean plasma total cholesterol and LDL cholesterol levels elevated in hypothyroid cases than in normal controls.

In another study, average serum total cholesterol level was found elevated in primary and secondary hypothyroidism $^{17}$.

Keyes \& Heimberg ${ }^{18}$, Laker \& Mayes $^{19}$ found triglyceride level elevated in hypothyroid patients. Thompson $^{20}$ and Abrams \& Grundy $^{21}$ have stated decreased activity of LDL receptors as the main cause of hypercholesterolemia in hypothyroidism.

\section{CONCLUSION}

We conclude that, dyslipidemias are associated with thyroid disorders, so biochemical screening for thyroid dysfunction in all dyslipidemic patients. Therefore, patients presenting with dyslipidemia are recommended for investigation to explore thyroid dysfunction. As our sample size was small and duration of study was limited, another study with large sample size and longer duration is also recommended.

\section{REFERENCES}

1. Shaikh BA. Clinical features of primary hypothyroidism: A year experience at Chandka medical college, Larkana. Medical Channel. 2008:14 (1): 72-5.

2. V. Sunanda, S. Sangeeta, B. Rao P. Int J Biol Med Res. 2012; 3(1): 1373-6.

3. Liberopoulos EN, Elisaf MS. Dyslipidemia in patients with thyroid disorders. Hormones 2002, 1(4):218-23.

4. Stone NJ. Secondary causes of hyperlipidemia. Med Clin North Am 1994; 78:117-41.

5. Guyton AC, Hall JE. The thyroid metabolic hormones. In: Textbook of medical physiology. 10th edn. New York: W B Saunders Company, 2000:858-68.

6. Thompson $G R$, Soutar $A K$, Spengel $F A$, Jadhav $A$, Gavigan S, Myant NB. Defects of the receptor mediated low density lipoprotein metabolism In 
homozygous familiar hypecholesterolemia and hypothyroidism in vivo. Proct Natl Acad Sci USA 1981; 78:2591-5.

7. Nikkilia EA, Kekki M. Plasma triglyceride metabolism in thyroid disease. J Clin Invest 1972; 51:2103-14.

8. Allian CC, Poon LS, Chan CSG, Richmond W, Fu P. Enzymatic determination of total serum cholesterol. Clin Chem 1974; 20(4): 470-5.

9. Trinder P, Ann Clin Biochem. 1969; 6: 24-7.

10. Burstein M, Scholnick HR, Morfin R. Rapid method for the isolation of lipoproteins from human serum by precipitation with polyanions. J Lipid Res 1970; 11(6): 583-95.

11. Tietz $\mathrm{N}$, (Ed) Fundamentals of Clinical Chemistry, W. B. Saunders, Philadelphia, PA, 1998.

12. Beyer IW, Karmali R, DeMeester-Mirkine N, Cogan E, Fuss MJ. Serum creatine kinase levels in overt and subclinical hypothyroidism. Thyroid 1998; 8:1029-31.

13. World Medical Association declaration of Helsinki. Ethical Principles for Medical Research involving Human subjects. World Medical Association available from; http://www.wma.net/e/policy/b3html.

14. Baral N, Lamsal M, Koner BC, Koirala S. Thyroid dysfunction in eastern Nepal. South Asian J Trop Med Public Health 2002; 33: 638-41.

15. Hollowell JG, Staehing NW, Flanders WD et al. Serum TSH, T4, and thyroid antibodies in the United States Population (1988 to 1994): National Health and
Nutrition Examination Survey (NHANES III). J Clin Endocrinol Metabol 2002; 87: 489-99.

16. Jung $\mathrm{CH}$, Sung $\mathrm{KC}$, Shin HS, Rhee EJ, Lee WY, Kim BS, Kang JH, Kim H, Kim SW, Lee MH, Park JR, Kim SW. Thyroid dysfunction and their relation to cardiovascular risk factors such as lipid profile, hsCRP and waist hip ratio in Korea. Korean J Intern Med 2003;18:146-153.

17. Skanse B. On the difference in serum cholesterol between hypothyroidism of pituitary and of thyroid origin. In: Pitt-Rivers R, Green R, Tata JR, McCartney W, Taylor S, Pochin EE, Trotter WR (eds). The fourth international goitre conference. London: Pergaman Press, 1961:108-118.

18. Keyes WG, Heimberg M. Influence of thyroid status on lipid metabolism in the perfused rat liver. J Clin Invest 1979;64:182-190.

19. Laker ME, Mayes PA. Effect of hyperthyroidism and hypothyroidism and carbohydrate metabolism of the perfused rat. Biochem J 1981;96:247-255.

20. Thompson GR, Soutar AK, Spengel F A, Jadhav A, Gavigan S, Myant NB. Defects of the receptor mediated low density lipoprotein metabolism in homozygous familiar hypecholesterolemia and hypothyroidism in vivo. Proct Natl Acad Sci USA 1981;78:2591-2595

21. Abrams JJ, Grundy SM. Cholesterol metabolism in hypothyroidsm and hyperthyroidism in man. J Lipid Res 1981;82:323-338. 